\title{
Only the Shipyards Will Gain: The Buffalo Hurricane of 1921 as a Demonstration of the Combined Economic Power of Commercial Carriers on the Great Lakes
}

\section{Jay C. Martin}

Le 18 décembre 1921, un ouragan a endommagé la flotte de vraquiers des Grands Lacs, mouillés à l'abri pour l'hiver, à Buffalo, New York. Soixante-deux navires ont été affectés. L'événement avait le potentiel de faire grimper le prix du blé, car une grande quantité de céréales a été stocké à bord des navires désarmés. Grâce à une action collective, les armateurs, assureurs, et l'Association des Transporteur des Lacs ont rapidement récupéré les vraquiers et leurs cargaisons. Le résultat a été une reprise rapide qui a non seulement maintenu une livraison ininterrompue du grain vers les marchés nationaux et internationaux, mais a également remis en service tous les navires à temps pour la saison record de 1922.

The focus of market-oriented enterprise is competition. Competing favorably against other companies or eliminating competition is a primary preoccupation. These imperatives are well-studied and familiar. However, less well-studied is how competitors cooperate for mutual advantage in times of shared emergency, both natural and manmade. But rarely is a localized disaster with potential regional, national, and even international repercussions able to foster a combined response by geographically diverse commercial competitors in a single industry. One event that demonstrates the critical impact of a highly coordinated response among commercial competitors is the great Buffalo hurricane of 18 December 1921. ${ }^{1}$

In this event the Lake Carriers Association - the industry umbrella group for American ship owners on the freshwater Great Lakes - worked closely with insurers, wreckers, and government agencies to quickly respond and recover a shipping community when a shared emergency occurred. The event happened just as the freshwater lakes were starting to freeze, limiting options for effective response.

\section{Background}

After the War of 1812 grain from the Great Lakes states and provinces of the

1 The author would like to acknowledge the assistance of Samantha Sullivan in the production of this article.

The Northern Mariner/Le marin du nord XXV, No. 2 (April 2015), 133-146 
United States and Canada began to trickle eastward to feed the people of eastern North America when the Erie Canal was completed in 1825. The incredible rise of this grain trade is marked by the entry of the Great Lakes into the world grain market. By the early 20th century the outflow of grain had become a flood with the potential to have an impact far beyond North American markets. ${ }^{2}$

Buffalo was the essential link in the Midwestern grain trade. Buffalo's position at the terminus of the upper Great Lakes (eastern Lake Erie at the beginning of the Niagara River), the west end of the Erie Canal, and multiple railroads made it the hub of major activity. Hundreds of cargoes of grain from the west and Midwest were loaded in Chicago, Milwaukee, Duluth, and other upper lakes ports and shipped to Buffalo for milling or transfer by rail to reach national and world markets. ${ }^{3}$ Cargoes delivered during the summer flowed into Buffalo elevators with amazing speed and efficiency, feeding a seeming insatiable need. But ice closed the lakes to navigation in the winter - roughly December to March, and sometimes later depending upon icing conditions and the willingness of insurers to issue marine policies - which brought disruption to the flow of grain.

The common practice at the time was to load lake bulk carriers with their last cargo in an upper lakes port during November or December before sailing to Buffalo to be laid up for the winter. They therefore served as temporary storage until the elevators needed their cargoes to maintain a steady stream of commodities. They were anchored out, nearly side to side between the shore and the breakwaters, moored against the weather with holds full to await unloading when the stocks of grain in the elevators ashore dwindled. Hence, the steady flow of grain was assured and this part of the economic engine powered by Great Lakes commerce was maintained. Toledo, Erie, Cleveland, and other lower lake ports also sheltered vessels in winter layup with grain cargoes, but Buffalo was dominant by a considerable margin. ${ }^{4}$

Buffalo was a challenging winter lay-up port. The harbor was not a natural, deep water embayment with good shelter for vessels of all sizes. Instead it was a minor bay on the east side of the Niagara River at the outflow of Lake Erie. The shelter it provided was man-made, composed of a series of riprap breakwaters set in a rough line three-anda-half miles long that divided the anchorage from the open waters of the lake. The breakwater system - funded largely by the United States government, built primarily by private contractors, and maintained by the United States Army Corps of Engineers provided 1,800-2,000 feet of space between the lake and the shoreline, including the 800 foot wide navigational channel. Unlike dockage along the river and canals of Buffalo, mooring out in the harbor was free and thus attractive to shipping companies. Under

2 Jay C. Martin, "Sailing the Freshwater Seas: A Social History of Life Aboard the Commercial Sailing Vessels of the United States and Canada on the Great Lakes, 1815-1930" (PhD Dissertation, Bowling Green State University, 1995), 22-25.

3 John G. Clark, The Grain Trade in the Old Northwest (Urbana: University of Illinois Press, 1966), 102-123.

4 "Shaughnessy Gets Late Trip Record," Detroit Free Press, 22 December 1921; "Soo is Waiting Last Grain Boat,” Detroit Free Press, 23 December 1921. 
normal conditions, the shelter adequately blocked the force of waves driven the length of Lake Erie, but was otherwise open to the elements. ${ }^{5}$ The piloting guide published as Survey of Northern and Northwestern Lakes warned that this mooring area was "subject to great storms from the southwest." ${ }^{6}$ The breakwaters did not block the wind, nor could they do more than slow down large waves and storm surge from prolonged southwest gales. The force of hurricane winds could not be defended against.

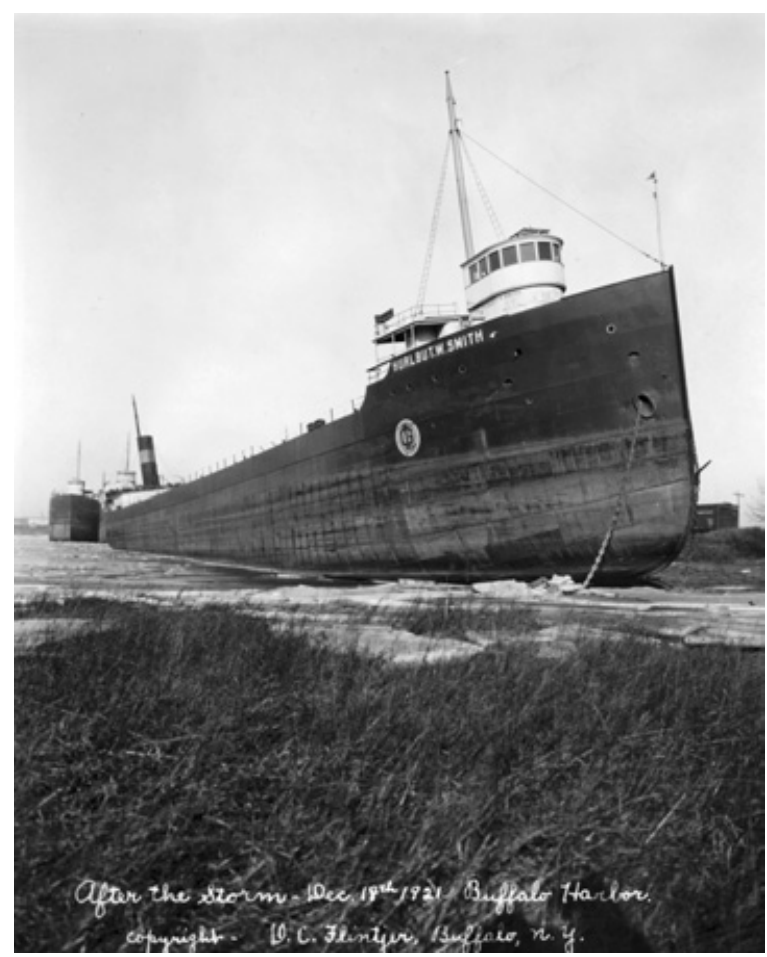

Illustration 1: The Hurlburt W. Smith was one of the bulk carriers left beached at Buffalo in the wake of the storm. Extensive dredging and pulling was required to release the stranded vessel. Historical Collections of the Great Lakes, Bowling Green State University.
On 20 January 1907, these frailties became apparent when a powerful storm with sustained southwest winds reaching 42 miles per hour put five boats moored inside the breakwater ashore, carried others moored in the river away from their docks, and damaged several elevators. Of the twenty-three boats in the harbor, the Spokane, George B. Leonard, William Nottingham, J.Q. Riddle, and Hurlburt W. Smith required extensive dredging and pulling to get off the beach. Several other boats were aground, but more easily refloated. The contract for salvaging the five boats ashore sparked an unproductive bidding war that slowed the process and resulted in a slow recovery. Ashore and afloat the storm caused an estimated $\$ 2,000,000$ in damage. ${ }^{7}$ Fortunately, so few boats carried a relatively small portion of the total storage grain and had no significant impact on the market. Yet, the 1907 incident highlighted as never before the vulnerability to shipping from strong southwesterly storms.

Afterward the shipping industry returned to normal. Shipyards built larger, more

5 Annual Report of the Lake Carriers Association, 1921 (Detroit: P.N. Bland Printing Company, 1922), 128 and Sketch Plan Showing Position of Vessels Immediately Following Hurricane Disaster, Buffalo Harbor, 18 December 1921; "Lake Boats Still Aground," New York Times, 21 December 1921, p. 6.

$6 \quad$ Survey of the Northern and Northwestern Lakes (Washington: GPO, 1931), 328.

7 "Two Millions Damage in Storm," Toledo Blade, 21 January 1907; "Driftwood," Toledo Blade, 29 January 1907; Toledo Blade, 30 January 1907; "Description of Buffalo Wind Storm," Marine Review (7 February 1907). 
efficient bulk carriers and the grain merchants invested in ever more commodious elevators. But the memory of how a "business as usual" response to a common emergency could slow recovery and drive up prices remained a lasting lesson to ship owners/managers, insurers, and the Lake Carriers Association.

The system worked well through the extraordinary demands of World War I, and in the economic uncertainty of the immediate post-war years was struggling to set a new level of normalcy. The 1921 season was one of the best on record. Farmers had a great growing season, resulting in an abundance of grain of all types. By 15 December shipments of over 12,500,000 bushels of grain - nearly twice as much shipped during 1920 - had made their way eastward on the New York State Barge Canal, the successor to the Erie Canal. As the Great Lakes shipping season approached closure, dozens of bulk carriers loaded with grain sailed from ports like Fort William, Ontario, and Superior, Wisconsin, bound for Buffalo with storage cargoes for winter layup. ${ }^{8}$ A new record for grain receipts in Buffalo was expected for 1921. The previous record of grain receipts via lake boat was $219,897,727$ bushels set in 1898 . Receipts for 1921 were anticipated to exceed 221,000,000 bushels. On 16 December Buffalo's lay up fleet already held $33,000,000$ bushels, with 1,036,000 in vessels at the elevators, and another 2,000,000 bushels in transit aboard the last down bound bulk carriers. This presumed that ice breakers were able to keep the locks at Sault Ste. Marie open until all the bulk carriers had reached Buffalo and other Lake Erie ports. ${ }^{9}$

Surplus production kept grain prices low, even with the annual cycle of purchases for the European market underway. The post World War I Russian economy - after the ouster of the Czar and the growing dominance of the Bolsheviks - was in disarray. Rumors of $\$ 20,000,000$ in United States aid in the form of wheat and corn purchases to provide Russian relief encouraged an initially strong showing on the New York stock exchange. The price of wheat, corn, and oats all rose slightly, but the rise was not sustained. ${ }^{10}$ Markets in Chicago and Detroit remained sluggish and in-flow diminished as farmers held out for higher prices, wishing for government intervention to drive wheat up to a guaranteed $\$ 2.50$ per bushel. Canadian and American farmers who had enjoyed high prices during World War I were struggling with debt from wartime expansion. The annual shortage of grain as winter stocks were expended in the spring and early summer was expected to bring the next price rise. Until then, the only aid to American farmers came in the form of a 16 percent reduction in railroad freight rates for grain shipment ordained by the Interstate Commerce Commission for implementation on 27 December. The distractions of the holiday season and difficulties of road transportation in the winter weather also slowed the flow of grain to market and the resulting sales. ${ }^{11}$ Australian and

$8 \quad$ “Grain Fleet is Due Today," Detroit Free Press, 16 December 1921.

9 "Two More Ships Will Load Grain," "Lake Grain Carriers May Need Ice Breakers" and "Buffalo Expects New Grain Traffic Record," Detroit Free Press, 17 December 1921.

10 "Russian Aid Gossip Lifts Wheat Price," Detroit Free Press, 16 December 1921; "Quiet Market for All the Grains," Detroit Free Press, 17 December 1921; "Little Interest in Grain Market," Detroit Free Press, 18 December 1921.

11 "Failed to Follow Chicago Advance," Detroit Free Press, 16 December 1921; "Financial 
Argentinian seasonal production was soon expected to impact prices, leading to considerable insecurity throughout the market. ${ }^{12}$

\section{The Event}

The shipping season was winding down on the third Sunday in December. Many Great Lakes bulk carriers were laid up for the season, avoiding the growing fields of ice in the north and the risk of sailing the unsheltered lakes during one of the most dangerous parts of the annual weather cycle.

The weather that swept into the region from the southwest on 17-18 December 1921 brought hurricane force winds, snow, and ice. On Saturday, 17 December, the United States Weather Bureau at Toledo reported a falling barometer, a decrease of temperature from fifty-five to thirty-seven degrees Fahrenheit, and winds in the fifty to sixty miles per hour range by midnight. Cleveland reported a similar pattern, with winds around fifty-three miles per hour just after 1:00 am. Fortunately, winds from the south and southwest came over land and were broken by trees and buildings, mitigating the impact so that the "severe wind storm ... did but little damage" in Toledo. ${ }^{13}$ Other areas were not as lucky.

The velocity of the wind picked up as the storm moved eastward, lashing shallow Lake Erie and picking up momentum as it moved northeastward. It reached Buffalo in the early hours of 18 December, bringing winds of seventy miles per hour that increased to eighty-four mph by 9:15 am and peaked at ninety-six mph at 10:15 am. ${ }^{14}$ The storm had reached hurricane strength as it descended upon Buffalo Harbor, where the breakwaters provided some protection from the waves, but not the force of the wind.

The effect on shipping was disastrous. On 18 December three Buffalo to Fort Eire ferries and ninety-four steel steamers - the most modern and efficient commercial fleet in the world - lay in Buffalo Harbor, most of the latter with fresh loads of storage grain. Sixty-two of these vessels lay anchored behind the riprap, bows toward the open lake beyond breakwaters in order to withstand weather from the southwest, the direction of the prevailing winds. Anchors set forward and aft and pilings driven into the lake bed provided "snubbing posts" to which hawsers were attached to further secure the boats. ${ }^{15}$ Most vessels had ship keepers - normally just one person per ship - whose duty was to care for the ships at their moorings.

Miracles" and "Board Upholds Grain Rate Cut," Detroit Free Press, 17 December 1921; "Little Interest in Grain Market," Detroit Free Press, 18 December 1921. "Little Interest in Grain Market," Detroit Free Press, 18 December 1921.

1921 (Toledo) Original monthly record of observations, 18 December 1921, GLMS-107 National Weather Service, Box 3, Folder 3, Historical Collections of the Great Lakes, Bowling Green University Center for Archival Collections; 1921 (Cleveland) Original monthly record of observations, GLMS-93 National Weather Service, Box 13, Folder 2, ibid. Annual Report of the Lake Carriers Association, 1921, 128 and Sketch Plan Showing Position of Vessels.

Ibid.; “95 Mile Gale Floods Buffalo; Niagara Rages," Chicago Daily Tribune, 19 December 1921. 
When the gale blew ashore huge seas and a "tidal wave" pounded the breakwaters, going over them into the anchorage. ${ }^{16}$ The pressure of hurricane force winds ripped twenty-seven boats from their moorings, colliding with each other as they moved en mass through the outer harbor like logs forced down a river in a flood. The ship keepers struggled to keep their vessels at their moorings, but found it impossible to handle an emergency on such a grand scale. There was little that they could do but ride the bulk carriers as they bumped together, dragging their anchors as they careened toward shore. Many vessels ended up in clumps and gangs twisted together with entwined anchor chains, but still in deep enough water to be easily returned to normal moorings when the storm subsided. Twenty-three steamers went ashore. Ten went ashore broadside to the waves, a precarious position indeed. The abnormally high water levels caused by the storm had deposited some vessels nearly high and dry, making removal a greater challenge. ${ }^{17}$

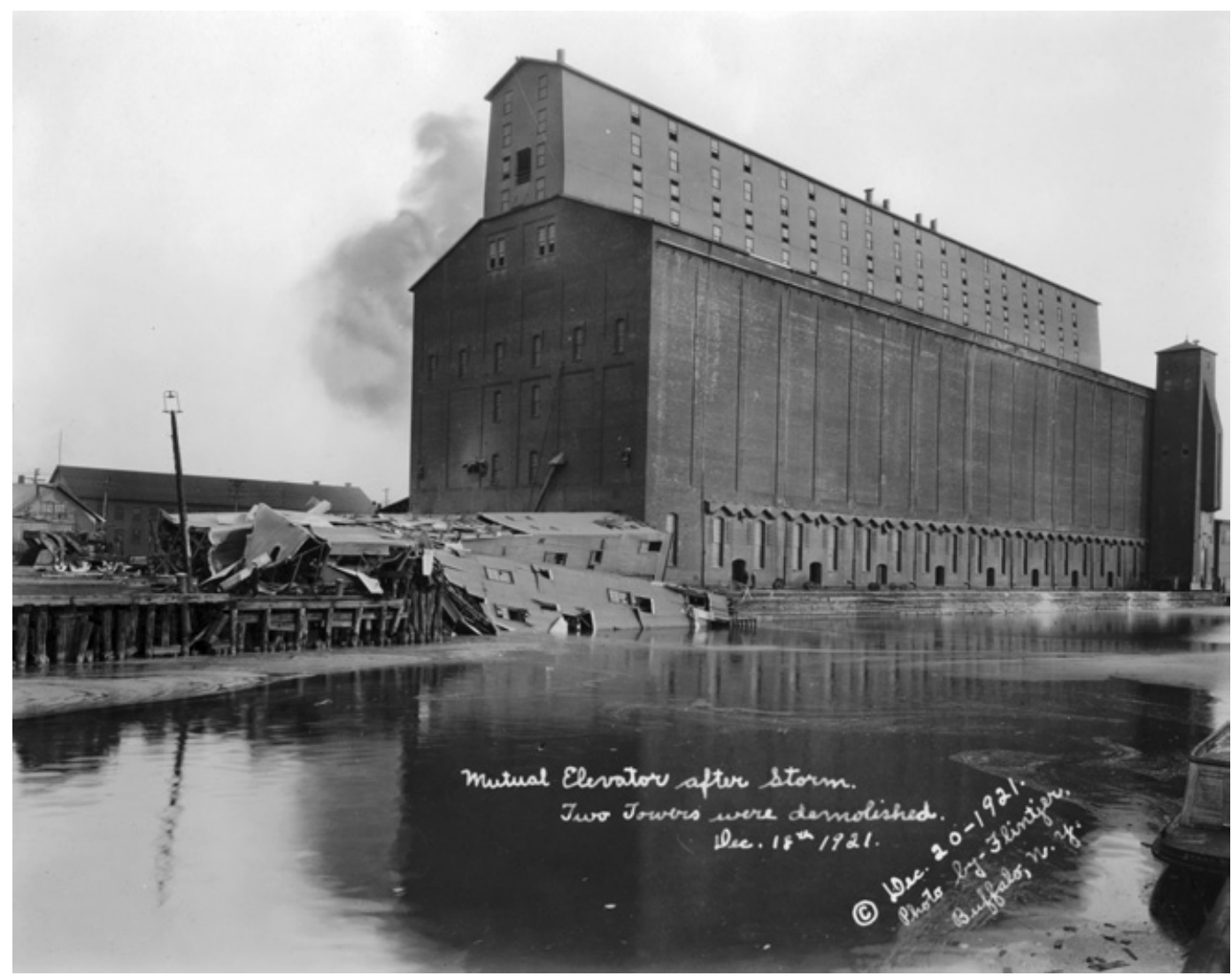

Illustration 2: Two towers of the Buffalo Mutual Elevator were collapsed by hurricane force winds, illustrating a small part of the damage sustained ashore. Historical Collections of the Great Lakes, Bowling Green State University.

16 "Damaging Gale Sweeps Up-State," New York Times, 20 December 1921, 7.

17 Annual Report of the Lake Carriers Association, 1921, 128 and Sketch Plan Showing Position of Vessels. 
Many actions of extraordinary innovation saved lives. A Dunbar and Sullivan dredge was anchored off Green Island before the storm. When the anchors began to drag, the captain made signs of distress. Tugs sent to retrieve the dredge before it took its crew over Niagara Falls were unsuccessful in stopping the momentum. The dredge captain used the dipper bucket to dig into the muddy river bottom, thus holding the vessel against the wind and massive current of the overflowing river, saving the lives of all on board. ${ }^{18}$

Not all of the damage was sustained on the water. Two towers of the Mutual Elevator were destroyed. ${ }^{19}$ A wireless tower, many docks, small boats, boat houses, and waterfront homes along the Niagara River were badly damaged or swept down river, as was the inventory of several lumber yards, damage estimated at over $\$ 500,000$. Bird, Squaw, Willow, Green, and the Three Sister Islands were almost completely submerged, the volume of water going over Niagara Falls being so great that the spray - tinted brown and yellow - froze on trees hundreds of feet back from the cataract. ${ }^{20}$

Countless chimneys toppled, trees uprooted, and windows blew in as the wind pushed "water in the harbor to an unprecedented stage." 21 In Buffalo, one man was killed when flying debris went through the windshield of his car and two sisters were badly hurt by a falling tree. Nearly one hundred squatters' shanties between the Barge Canal and the Niagara River were smashed, some of the occupants were carried out in the river with their homes, to be rescued later by the Buffalo Police, Fire Department, and the United States Coast Guard. ${ }^{22}$ Street car service was interrupted on the morning of 18 December, but was largely restored by the end of the day. Power lines were down throughout the region. In Tonawanda and North Tonawanda water eight feet above flood-stage submerged the first floors of shoreline businesses. ${ }^{23}$

Serious damage was reported at Dunkirk, Rochester, Johnstown, Binghampton, Syracuse, Utica, Ploughkeepsie, the Bronx, Quebec City, and Ogdensburg. Telephone and telegraph communication between Quebec City and Montreal were disrupted. On Lake Michigan, the Grand Trunk Railroad carferry Milwaukee battled the storm for hours, requiring an additional thirteen hours to cross the lake from Grand Haven to Milwaukee, normally a six hour run. ${ }^{24}$ Page one of the Detroit Free Press covered the presumed loss of the Canadian lighthouse tenders Patria and Concretia on Lake Ontario. ${ }^{25}$

18 “Damaging Gale Sweeps Up-State," New York Times, 20 December 1921, 7.

19 Annual Report of the Lake Carriers Association, 1921, 131.

20 "Damaging Gale Sweeps Up-State" and "\$1,500,000 in Storm Damage: Vessels at Niagara Falls and Buffalo Suffered in Gale," New York Times, 20 December 1921.

21 “95 Mile Gale Floods Buffalo; Niagara Rages,” Chicago Daily Tribune, 19 December 1921.

22 “Damaging Gale Sweeps Up-State,” New York Times, 20 December 1921.

23 Ibid.

24 Ibid.; "95 Mile Gale Floods Buffalo; Niagara Rages," Chicago Daily Tribune, 19 December 1921; "Storm Sweeps Michigan, East," Detroit Free Press, 19 December 1921; George W. Hilton, The Great Lakes Car Ferries (Berkeley, CA: Howell-North Books, 1962), 177. 


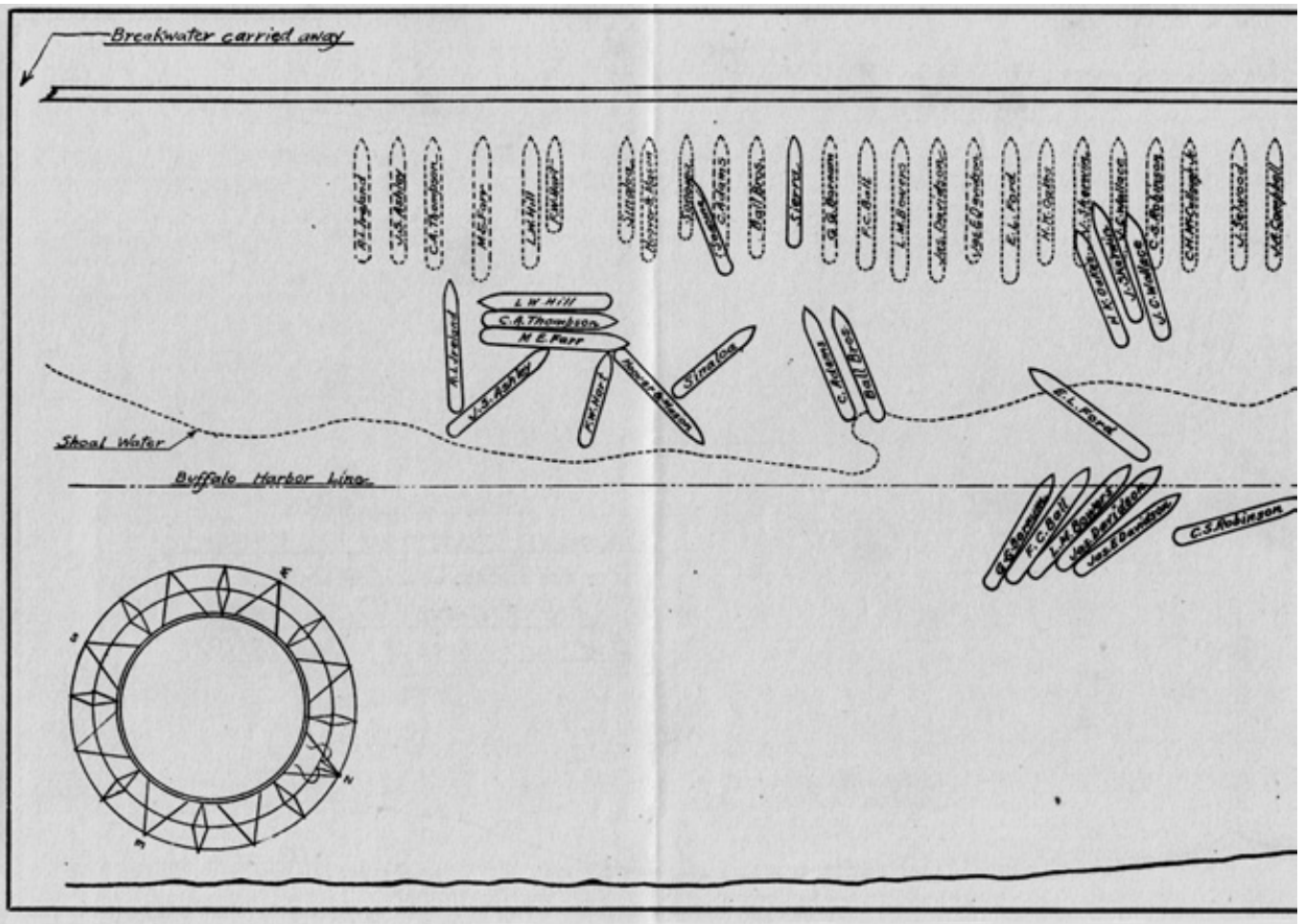

Illustration 3: To better understand the failed moorings in Buffalo, the Lake Carriers Association commissioned a map to show the positions of the largest cluster of bulk carriers before and after the storm.

On the west shore of Lake Erie and the lower Detroit River maritime traffic was delayed by a dramatic lowering of the water level as wind pushed water from west to east down the lake. At Toledo the Maumee River dropped ten feet, leaving freighters at winter moorings off Bay View sitting in the mud. At Lime Kiln Crossing the water level dropped six feet. The Detroit Free Press reported that "old mariners say not in years has the water level here reached such a low stage." 26 Maritime affairs all over the region were temporarily in disarray.

\section{Recovery}

When the storm subsided, the Great Lakes shipping community was faced with a chaotic and confusing mess. At stake were vessels valued at $\$ 14,000,000$ carrying grain valued at $\$ 7,000,000$ - together equivalent to roughly $\$ 279,000,000$ today - and costs to preserve the ships, save the grain cargoes, and restore the fleet to service before spring. Damage to the fleet was serious. A few gashed and punctured steel plates existed, but more common were dented plates, bottom damage, and torn and twisted mooring gear.

26 "Gale Lowers Water Six Feet at Amherstburg" and "Storm Sweeps Michigan, East," Detroit Free Press, 19 December 1921. 


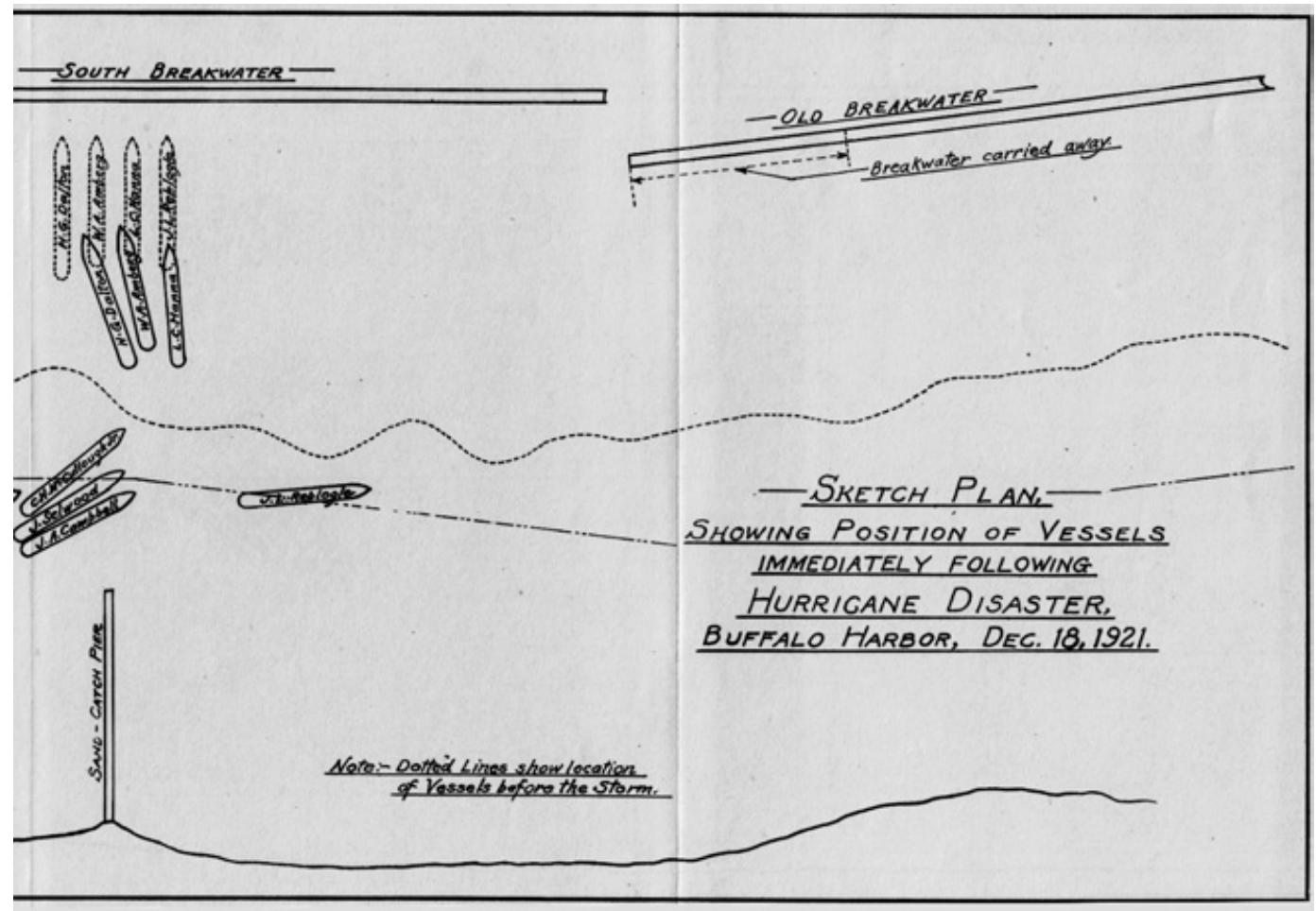

Illustration 3 (continued): see caption opposite.

All vessels required the attention of salvage crews and tugs to refloat and remoor them. Many required lighters to transfer enough of the grain to lighten them so that they could be refloated to deeper water. ${ }^{27}$

Fleet managers converged on Buffalo on Monday, 20 December, to review the situation with the twenty-two stranded bulk carriers. The Detroit Free Press reported:

The boats are nearly all on the bottom, a veritable tangled network of anchor chains, cables, and anchors. Several of them were jammed against each other, the chains and anchors crossed in such a chaotic manner that it will take days, perhaps weeks, to get them untangled. Marine experts of years' experience declared they never had seen such a mess along the lakes as these boats are in at present. ${ }^{28}$

G.A. Tomlinson and Company was in the most serious position with twelve boats on the beach, including the L.M. Bowers, James Davidson, and Merton E. Farr, new ships that had entered service within the prior eighteen months. The Interlake Steamship

27 Annual Report of the Lake Carriers Association, 1921, 128-130 and Sketch Plan Showing Position of Vessels; "22 Big Steamers Ashore at Buffalo," Chicago Herald and Examiner, 20 December 1921; "One Drowned During Storm," Toledo Blade, 19 December 1921. 
Company had five boats aground, M.A. Hanna and Company had three, Kinney Steamship Company had two, and Herbert K. Oakes one. ${ }^{29}$

A meeting Monday night brought together vessel owners, underwriters, American Bureau of Shipping representatives, and salvors. H. Parry Jones, representing the American Bureau of Shipping, suggested that everyone work together, moving the boats that could be floated quickly out of the way to their moorings so that the more badly damaged could be reached. ${ }^{30}$ The lighters Rescue and Reliance were dispatched from Detroit to help with the job. ${ }^{31}$ The unprecedented scale of the disaster led the shipping companies, insurers, and shipyards to unite to sort things out. ${ }^{32}$

Coordination of a salvage job as big as this involving multiple wrecking firms was presumed too much to be left uncoordinated. To do so would require shipping companies to fight over scarce resources. Working together seemed the only approach, and putting the work under one man seemed most appropriate. George Lynn, superintendent for the Great Lakes Steamship Company, was chosen for the job. ${ }^{33}$ Although the Great Lakes Steamship Company had few vessels damaged in comparison to other fleets, Lynn was chosen because he was a thirty-three year veteran of the shipping industry of high energy who "stands among the foremost of his craft." ${ }^{34} \mathrm{He}$ had previously served as chief engineer of the Pittsburgh Steamship Company, the largest Great Lakes fleet with nearly one hundred vessels. He was therefore adept at handling multiple issues at one time.

By 20 December, Lynn had mobilized equipment from as far away as Port Huron and used all the resources available to him, particularly the Great Lakes Towing Company, which worked dawn to dusk refloating the stranded freighters that were easiest to recover. Salvors were able to get the steamers C.H. McCullough, Jr., and J.C. Wallace off first. They were soon on their way back to their offshore mooring berths. ${ }^{35}$ By afternoon the salvors had refloated and remoored A.T. Kinney, W.P. Snyder, Jr., James P. Walsh, Howard M. Hanna, Jr., and William Livingstone. The H.G. Dalton and J.C. Wallace had to be temporarily remoored in order to facilitate work. By evening Emory $L$. Ford and H.K. Oakes were removed and remoored with their stern anchor chains still

29 Ibid.; Jay C. Martin, American Ship Building Company and Predecessors (Perrysburg, OH: Institute for Great Lakes Research, 1990), 64, 77; "Lake Fleet Swept by Terrific Gale," Marine Review (February 1922): 79.

30 "2 Ships, 24 Men Given Up For Lost in Storm," Detroit Free Press, 20 December 1921; "Lake Fleet Swept by Terrific Gale," Marine Review (February 1922): 79.

31 "2 Ships, 24 Men Given Up For Lost in Storm," Detroit Free Press, 20 December 1921.

32 Annual Report of the Lake Carriers Association, 1921, 129-130 and Sketch Plan Showing Position of Vessels.

33 "Part of Stranded Fleet is Floated," Detroit Free Press, 21 December 1921; "Lake Fleet Swept by Terrific Gale," Marine Review (February 1922): 79.

34 "New H.S. Wilkinson Will Be One of Biggest Freighters," Buffalo Daily Courier, 15 November 1916; Officering and Manning of Vessels: Hearings Before the Committee on Commerce United States Senate (Washington: GPO, 1913), 37.

35 "2 Ships, 24 Men Given Up For Lost in Storm," Detroit Free Press, 20 December 1921. 
tangled. The lighter Pittsburgh went along side the grounded Samuel Mather and the unloaded steamer Victory was placed on the outboard side of the scow so that Mather's cargo could be lightered into the empty holds of the Victory. The lighter Rescue arrived from Detroit in tow by the tug Virginia at 4:30 pm and went to work removing the cargo of the steamer J. Leonard Replogle, stranded at the extreme northern end of the pile up. ${ }^{36}$

Daily progress reports appeared in Great Lakes port newspapers, documenting the 22 December movement of the J.C. Wallace to the Superior Elevator and the Shenango to the Frontier Elevator to unload. The unentanglement of the steamer W.H. Becker was ongoing, with the plan to remoor her as soon as practical. Pittsburgh and Victory were still lightering the Mather, in hopes that a rise in the water level would allow tugs to pull her off. The work was particularly "tedious" because of the way "in which many of the ships are jammed against each other and the chaotic entanglement of anchor chains." 37 That evening Lynn estimated that it would take at least sixty days with favorable conditions to get the mess cleaned up. Visible damage to the bulk carriers was estimated at $\$ 700,000 .^{38}$

Friday, 23 December, was a challenging day for the salvage effort. A fire began in the coal bunker of the Hanna steamer Replogle, temporarily distracting the wreckers from moving and lightering operations. Support from the tug Gratton extinguished the fire. Damage to the ship was minor and left the cargo apparently unharmed. The Pittsburgh worked all night to lighter the cargo of the Joseph Sellwood into Victory. As a result, Sellwood was pulled off on Friday. Efforts to remove the Samuel Mather were unsuccessful. Wreckers got the Cuyler Adams and Ball Brothers off the beach and remoored. Release of the L.W. Hill and Sinaloa was attempted unsuccessfully. ${ }^{39}$

On 26 December the Sinaloa finally came off. The Replogle failed to come off and lighters began to take out more cargo. Great Lakes Dredge and Dock Company's Derrick Scow No. 44 began lightering the cargo of L.W. Hill into the C.M. Warner. Pittsburgh was lightering the J.A. Campbell. Crews under Captain Ben Broderick, Captain John Drury, and Captain F. Weinheimer worked to untangle the mooring lines and anchor chains, thus saving expensive gear for reuse. ${ }^{40}$ The C.S. Robinson and Samuel Mather were finally released on 28 December. $^{41}$

By 29 December most of the grounded vessels were afloat, and by the first week in January many were distributed to take advantage of competition among shipbuilding and repairing firms. The Hoover and Mason, the most damaged of all,

36 "Part of Stranded Fleet is Floated," Detroit Free Press, 21 December 1921.

37 “Tugs Find Ships Hard to Release,” Detroit Free Press, 23 December 1921.

38 Ibid.

39 "Shipbuilding Co. to Boost Force," Toledo Blade, 23 December 1921; "Fire on Replogle is Soon Put Out," Detroit Free Press, 26 December 1921.

40 "Stranded Boats Lighter Grain,” Detroit Free Press, 27 December 1921.

41 “Damaged Vessels Go To Shipyards," Detroit Free Press, 30 December 1921 


\section{ABSTRACT OF MASTER'S EXTENDED PROTEST}

We came to anchor in outer Buffalo Harbor Nov. 30 and on Dec. Ist got out four anchors and the vessel lay at anchor to wait until called upon to discharge her cargo. On Dec. 18, 1921 during the violent gale the Str. Sinaloa which lay to our port side, about $9 \mathrm{~A} . \mathrm{M}$. dragged her anchors and came against our port side and we then dragged onto the Str. Sonorna and our starboard anchor chain got foul of the Sonoma's fender strake and parted. Te then drifted astern and ietched up with our starboard side against the stem Str. F. M. Hart. In the terrific gale and seas it made we lay pounding against the stem of the Hart and our bow gradually went aheac and worked around to starboard so that we lay with our starboard quarter against the starboard bow of the Hart. He are now hard aground so that we are out over 7 feet forward and over two feet aft and leaking and the vessel her cargo and freight are in peril from wind and seas and from further damage by reason of being against the Hart and Farr, and tugs lighter and men are necessary to release the vessel and save vessel cargo and freight. After we fetched up the Str. Farr struck our stern with her starboard bow and lay banging up against our stern. Tle lost one anchor and chain and may have lost or damaged more chains, cables and anchors, lashings of rudder were carried away, in the pounding against the Sinazoa, Sonoma, Hart and Farr the vessels sides bows and stern were damaged; plating and frames bulkhead and decks broken, bent, dented, buckled; rivets broken and loosened; butts and seams opened; hawse pipes and windlass strained and damaged Iffe boat davits carried away on starboard side and lifeboat damaged, bottom dameged in pounding bottom and dragging our anchors, overboard pipes in engine room strained and broken, scupper plpes broken and steel partitions in fantali buckled and broken. Cargo may be wet and damaged from sea water. Rudder and shoe, propeller and shaft may be damaged. Te fitted out one boiler immediately and worked pump to keep water down and used fuel and oll for that purpose. Examination will be necessary to ascertain the full extent of the damage.

The moorings of said vessel had been prior to this disaster inspected and approved by the American. Bureau of Shipping and certificate of proper mooring is sued.

Illustration 4: The insurance claim for Hoover and Mason contained a brief summary of the bulk carrier's travails during the storm. This description illustrates how confused the situation was for ship keepers who struggled to keep their vessels from leaving their winter moorings, striking or being struck by other vessels, and going onto the beach. 
went to the American Ship Building Company yard in Lorain for the repair of sixty-eight damaged bottom plates, stem, and stern shoe. Some were repaired quickly, including the W.C. Richardson which had four plates replaced at Buffalo. Shenango and Andrew S. Upson followed herinto the Buffalo yard for repairs. ${ }^{42}$ All of the vessels involved in the grounding were drydocked for survey. Drydocking was a slow business because all ofthe boats needed to wait their turn to be unloaded first before entering a handful of drydocks in Lake Erie ports. ${ }^{43}$ In all, eight were repaired at Lorain, three at Cleveland, one at Ashtabula, and the balance at Buffalo. ${ }^{44}$

Twelve bulk carriers were still aground at year's end, waiting to have cargo lightered so that they could be dragged back into deep water. ${ }^{45}$ The badly damaged Merton E. Farr was finally released after lightering 50,000 bushels of grain and the intervention of a southwest gale on 4-5 January 1922 which raised the water level four feet. In all, it took three weeks to regain order on the Buffalo waterfront. ${ }^{46}$

The insurance payout made by Marsh and McClellan - at the time one of the largest insurance agencies in the world - alone was $\$ 445,602.54$ toward damages totaling $\$ 509,000.85$ to thirteen vessels of the G.A. Tomlinson fleet and one (Amazon) of the Hutchison fleet. ${ }^{47}$ The final direct cost of the disaster to the shipping community was nearly $\$ 2$ million. The cargo loss was minimal, very little being damaged by wetting or fire, or lost through lightering.

Wheat prices rose slightly on the early reports that "several grain ships had grounded at Buffalo and damaged their cargoes" 48 but the quick action to save the fleet and minimize spoilage in cargo, stabilized the market. ${ }^{49}$ The spring brought a stronger than usual demand for grain. By March most of the elevators had unloaded the vessel storage grain and 5,000,000 more bushels had been exported than in the previous year. ${ }^{50}$ The quick action to save the boats damaged the previous December had correspondingly saved cargoes that were now important to maintain strong exports.

Fortunately, the damage occurred at the end of the season (December) rather than at the start of a new shipping season (March) when there could have been significant disruption to service. Otherwise, the dependence that America had developed for the maritime commerce of the Great Lakes might have been severely felt. Instead, the 1922 shipping season started on time with no measurable negative impact.

42 Ibid.; "Lake Fleet Swept by Terrific Gale," Marine Review (February 1922): 79, 85.

44 "Lake Fleet Swept by Terrific Gale," Marine Review (February 1922): 79, 85.

45 "Stranded Vessels Have to Lighter," Detroit Free Press, 31 December 1921.

46 "Buffalo Grain Fleet Target of 96-Mile Gale in 1921; 21 Vessels Blown on Beach," Lake Carriers Association Bulletin (November-December 1966): 10-11.

47 Marsh and McLennan Collection, GLMS-33, Historical Collection of the Great Lakes, Bowling Green State University Center for Archival Collections.

48 “Corn Plentiful, Prices Decline," Detroit Free Press, 21 December 1921.

49 "Close in Wheat is Near Highest," Detroit Free Press, 20 December 1921.

50 "Buffalo Ships Much Grain for Export," Detroit Free Press, 2 March 1922. 


\section{Conclusion}

All of the bulk carriers damaged during the Buffalo hurricane returned to service during the 1922 shipping season. Of the forty-nine vessels identified by Marine Review as part of the incident, the average longevity was 61.53 years, a length of time that was reasonable by freshwater standards. ${ }^{51}$ Ironically, at least one of the boats - the Hurlburt W. Smith - was also damaged in the 1907 Buffalo grounding event.

Port rival Toledo saw in this disaster an opportunity to boost its own winter mooring fleet since vessels at Bay View were sheltered from the southwest and survived the storm without damage. However, the convenience of holding storage grain cargoes close to the major elevators at Buffalo permitted the bigger port to maintain its dominance. ${ }^{52}$

Hoping to avoid the delays and bidding war associated with the 1921 Buffalo incident, the Lake Carriers Association working with the American Bureau of Shipping and the individual shipping companies made all the difference in minimizing cost by coordinating the efforts of salvors and shipyards, removing vessels in a logical sequence that did not give preference to any one fleet, and using time effectively to minimize negative impact to the industry. Choosing one highly experienced individual from a fleet with minimal losses to control the entirety of the work and make decisions in the best interest of all based on logic, availability of resources, and extensive local knowledge promoted efficiency above all. The emergency response to the Buffalo Hurricane of 1921 stands as a classic an example of the value of cooperative action taken to benefit an entire industry.

51 Longevity was calculated based on the years boat were in service, as contained in Master Sheets, Historical Collections of the Great Lakes, Bowling Green State University, and Jay C. Martin, American Ship Building Company and Predecessors, 1867-1920 (Bowling Green: Institute for Great Lakes Research, 1988).

52 "Shipbuilding Co. to Boost Force," Toledo Blade, 23 December 1921. 